\title{
Pulse Radiolysis of Neopentane in the Gas Phase*
}

\author{
R. E. Rebbert and P. Ausloos \\ Institute for Materials Research, National Bureau of Standards, Washington, D.C. 20234
}

(February 9, 1972)

\begin{abstract}
The pulse radiolysis of gaseous neopentane has been investigated in the absence and presence of electron scavengers $\left(\mathrm{SF}_{6}, \mathrm{CD}_{3} \mathrm{I}, \mathrm{CCl}_{4}\right)$. Deuterium labeling experiments show that the stable product molecules can be accounted for by (a) radical combination reactions involving mainly $\mathrm{CH}_{3}$ and $\mathrm{H}$; (b) hydride ion transfer reactions involving $\mathrm{C}_{2} \mathrm{H}_{3}{ }^{+}, \mathrm{C}_{2} \mathrm{H}_{5}{ }^{+}$, and $\mathrm{C}_{3} \mathrm{H}_{5}{ }^{+}$; (c) neutralization reactions of $\mathrm{C}_{4} \mathrm{H}_{9}{ }^{+}$and $\mathrm{C}_{5} \mathrm{H}_{11}{ }^{+}$; and (d) unimolecular dissociation of the parent ion $\left(\mathrm{C}_{5} \mathrm{H}_{12}{ }^{+}\right)$and of electronically excited neopentane. Neutralization of the $t-\mathrm{C}_{4} \mathrm{H}_{9}{ }^{+}$ion, which is the major positive ion in the system occurs as follows: (a) $t-\mathrm{C}_{4} \mathrm{H}_{9}++e \rightarrow i-\mathrm{C}_{4} \mathrm{H}_{8}+\mathrm{H}$ and (b) $t-\mathrm{C}_{4} \mathrm{H}_{9}++e \rightarrow 2 \mathrm{CH}_{3}+\mathrm{C}_{3} \mathrm{H}_{6}$. It is shown that $\mathrm{C}_{5} \mathrm{H}_{11}{ }^{+}$produced in hydride ion transfer reaction $\mathrm{C}_{n} \mathrm{H}_{m}{ }^{+}+$neo- $\mathrm{C}_{5} \mathrm{H}_{12} \rightarrow \mathrm{C}_{n} \mathrm{H}_{m+1}+\mathrm{C}_{5} \mathrm{H}_{11}{ }^{+}$(where $\mathrm{C}_{n} \mathrm{H}_{m}{ }^{+}=\mathrm{C}_{2} \mathrm{H}_{3}{ }^{+}, \mathrm{C}_{2} \mathrm{H}_{5}{ }^{+}$, and $\left.\mathrm{C}_{3} \mathrm{H}_{5}{ }^{+}\right)$rearranges to the $\mathrm{CH}_{3} \mathrm{C}^{+}\left(\mathrm{CH}_{3}\right) \mathrm{CH}_{2} \mathrm{CH}_{3}$ structure prior to neutralization. A detailed accounting of all products produced in the unimolecular and bimolecular reactions led to the conclusion that the ratio of neutral electronically excited molecules to parent ions $\left(\mathrm{N}_{\mathrm{ex}} / \mathrm{N}_{+}\right)$is 0.28 .
\end{abstract}

Key words: Electron scavengers; gas phase; ion-molecule reactions; neopentane; neutralization; pulse radiolysis.

\section{Introduction}

Although nearly 500 papers dealing with pulse radiolysis have appeared in the literature, pulse radiolysis studies of alkanes in the gas phase are nonexistent, with the exception of two cursory studies of methane [1]. ${ }^{1}$ The reason for this is that it has become customary to associate direct detection techniques with pulse radiolysis experiments, and these techniques can not be readily applied to hydrocarbon gases. Actually, in the case of hydrocarbons (with the exception of aromatics), the absorption spectra of most of the fragment ions and free radicals, which are known to be present, have never been observed [2].

The limitations of optical absorption techniques for these systems do not, however, rule out pulse radiolysis as a powerful tool in the elucidation of the chemical changes brought about by high energy irradiation of hydrocarbon gases. Indeed, the pulse irradiation of judiciously selected hydrocarbons, or hydrocarboncontaining mixtures, followed by chemical analysis of the end products, may yield a wealth of information which will contribute to our overall understanding of radiolytic phenomena.

The main distinguishing feature of high dose rate pulse radiolysis experiments is the short lifetime of the charged species. Neutralization will be entirely homogeneous and reactions of ions with minor impurities or accumulated products will be negligible. Furthermore, the absence of long ionic chain reactions simplfies the

\footnotetext{
*Work supported in part by the Atomic Energy Commission.
}

${ }^{1}$ Figures in brackets indicate the literature references at the end of this paper. interpretation of the initial unimolecular and bimolecular reactions.

The present study which is the first in a series devoted to the pulse radiolysis of alkanes deals with neopentane. This molecule was chosen for the present exploratory study, because of the relatively limited number of reactive intermediates produced and because the low dose rate radiolysis has been investigated [3]. In the discussion which follows, the unimolecular and bimolecular reactions contributing to the formation of the products will be examined, by taking advantage of the same diagnostic isotopic labeling techniques which were successfully employed in earlier low dose rate investigations [3].

\section{Experimental Procedure}

\subsection{Pulsed Electron Beam Sources}

Two different electron pulse instruments, the Febetron 705 and $706,{ }^{2}$ were used in this study. These pulse sources are capacitor-discharge type instruments which use the field emission effect to obtain a high current of electrons from fine tungsten needles in a vacuum tube. The Febetron 705 has a half-maximum pulse duration of about $55 \mathrm{~ns}$ at maximum output (35 $\mathrm{kV}$ charging voltage, $4000 \mathrm{G}$ focusing field). The beam contains approximately $2 \times 10^{15}$ electrons per pulse with a mean energy of $1.4 \mathrm{MeV}$. At lower charg-

${ }^{2}$ Certain commercial equipment is identified in this paper in order to specify adequately experimental procedure. This identification does not imply recommendation or evaluation of this equipment by the National Bureau of Standards. 
ing voltages the half maximum pulse duration is somewhat longer (about $75 \mathrm{~ns}$ at $16 \mathrm{kV}$ charging voltage) and there are fewer electrons per pulse. The electron beam has a diameter of 3-4 cm just outside the thin titanium window of the instrument. For a given diode tube, the pulse-to-pulse reproducibility is excellent with a maximum deviation from the average of about 6 percent and an average deviation of less than 3 percent [4].

The Febetron 706 has half maximum pulse duration of about $3 \mathrm{~ns}$ at maximum output $(30 \mathrm{kV}$ charging voltage). The beam contains approximately $2 \times 10^{14}$ electrons per pulse with a nominal energy of $600 \mathrm{keV}$ and it has a diameter of about $1.4 \mathrm{~cm}$ just outside the window of the tube. For a given diode tube the pulseto-pulse fluctuations are less than 5 percent mean square deviation [5].

A few flash photolysis experiments were carried out in the course of this study using the flash apparatus constructed by W. Braun [6].

\subsection{Radiation Cells}

The radiation cells used in this work were cylindrical borosilicate glass vessels $10 \mathrm{~cm}$ long and $3.7 \mathrm{~cm}$ internal diameter with a volume of $106 \mathrm{~cm}^{3}$. Aluminum windows which were 4 mil thick were attached to each end of the cell with a vacuum epoxy cement. These cells were evacuated and filled through a PTFE valve and the reactants were condensed in a small finger at the bottom of the cell with liquid nitrogen. The outside of the cell was covered with aluminum foil which was grounded when the cell was irradiated by the electron pulse. These cells were very carefully positioned as close as possible in front of the titanium window of the Febetron.

In some of the early experiments cylindrical stainless steel cells were used which were $10 \mathrm{~cm}$ long and $4.7 \mathrm{~cm}$ internal diameter with a volume of $175 \mathrm{~cm}^{3}$. The 4 mil aluminum windows were attached with dairy clamps and viton O-rings. Essentially similar results were obtained with either the stainless steel or the borosilicate glass cells.

\subsection{Materials and Analysis}

Most of the chemicals used in this investigation were of research grade quality and except for degassing there was no further purification. Two different sources of neopentane were used, but there was no substantial difference in the results obtained with different samples. Neopentane- $d_{12}$ was purified on a gas chromatograph and checked on a mass spectrometer. It contained 8 percent $\mathrm{C}_{5} \mathrm{D}_{11} \mathrm{H}$. The $\mathrm{CD}_{3} \mathrm{I}$ contained 9 percent $\mathrm{CD}_{2} \mathrm{HI}$. The nitric oxide was stored over silica gel.

After the irradiation by the electron pulse(s), an aliquot of the mixture was injected onto a squalane column of a gas chromatograph with a flame ionization detector for quantitative analysis of the products. In those experiments in which the isotopic distributions of some of the products were determined, the hydrogen and methane were distilled at either liquid nitrogen or solid nitrogen temperatures. Then the remainder of the mixture was injected onto a silica gel column and the various products were trapped at the exit of the column in borosilicate glass spiral traps maintained at liquid nitrogen temperature and were analyzed on a mass spectrometer.

\subsection{Dosimetry}

Nitrous oxide at 1 atm pressure was used as the dosimetric gas using $\mathrm{G}\left(\mathrm{N}_{2}\right)=12.4$ as determined by Willis et al. $[4,7]$. The relative stopping power per electron of neopentane to nitrous oxide or air was calculated from the tables of Berger and Seltzer [8] as 1.05 for $600 \mathrm{keV}$ electron (Febetron 706) and 1.03 for $1.4 \mathrm{MeV}$ electrons (Febetron 705). The dosimetry experiments were performed in the same cells that were used to irradiate the neopentane mixtures so that there is no error due to a difference in geometry of the cells. One pulse emitted by the Febetron 706 ( 3 ns pulse) operated at a charging voltage of $30 \mathrm{kV}$ corresponded to a dose of $3.6 \times 10^{19} \mathrm{eV} / \mathrm{g}$. The dose per pulse $(\sim 60 \mathrm{~ns})$ from the Febetron 705 was 18.2 and $5.8 \times 10^{19} \mathrm{eV} / \mathrm{g}$ at charging voltages of 30 and $16 \mathrm{kV}$ respectively.

\section{Results}

The yields of the measured products are given as molecules, $\mathrm{M}$, of product $\mathrm{X}$ produced per ion pair, $\mathrm{N}_{+},\left(\mathrm{M}(\mathrm{X}) / \mathrm{N}_{+}\right)$[9]. A $W$-value of $23.2 \mathrm{eV}$ for neopentane was chosen to convert number of molecules per $\mathrm{eV}$ to the number of molecules per ion pair [10].

Table 1 gives all of the lower hydrocarbon products whose ion pair yields have been determined. In addition the ion pair yields of 2-methyl-1-butene (0.066), 2-methyl-2-butene (0.025) and 2,2-dimethylbutane $(0.050)$ were determined. Addition of $\mathrm{SF}_{6}$ increased the yields of 2-methyl-1-butene, 2-methyl-2butene and 2,2-dimethylbutane to $0.09,0.03$ and 0.068 respectively. Minor products such as $n$-butane $(<0.001)$ and propane $(\sim 0.01)$ are not listed in table 1 .

Tables 2 and 3 present isotopic analyses of hydrocarbon products produced in the pulse radiolysis of equimolar neo- $\mathrm{C}_{5} \mathrm{H}_{12}-$ neo- $\mathrm{C}_{5} \mathrm{D}_{12}$ mixtures. The hydrogen was also analyzed mass spectrometrically. In the pure neopentane mixture it consisted of $\mathrm{H}_{2}$ (50.1\%); $\mathrm{HD}(26.2 \%)$ and $\mathrm{D}_{2}(23.7 \%)$. Addition of 1 mol percent $\mathrm{SF}_{6}$ did not alter this distribution in any appreciable way, giving $\mathrm{H}_{2}(47.1 \%)$; $\mathrm{HD}(29.5 \%)$ and $\mathrm{D}_{2}(23.4 \%)$.

Table 4 contains the isotopic analyses and ion pair yields of the hydrogen, methane, and ethane produced in the pulse radiolysis of neo- $\mathrm{C}_{5} \mathrm{H}_{12}-\mathrm{CD}_{3} \mathrm{I}$ mixtures. The propylene and isobutene which were analyzed as well, contained less than 2 percent of the deuterium labeled species.

\section{Discussion}

The emphasis in this discussion will be mainly on the chemical consequences of the neutralization of 
TABLE 1. Pulse radiolysis of neopentane product yields

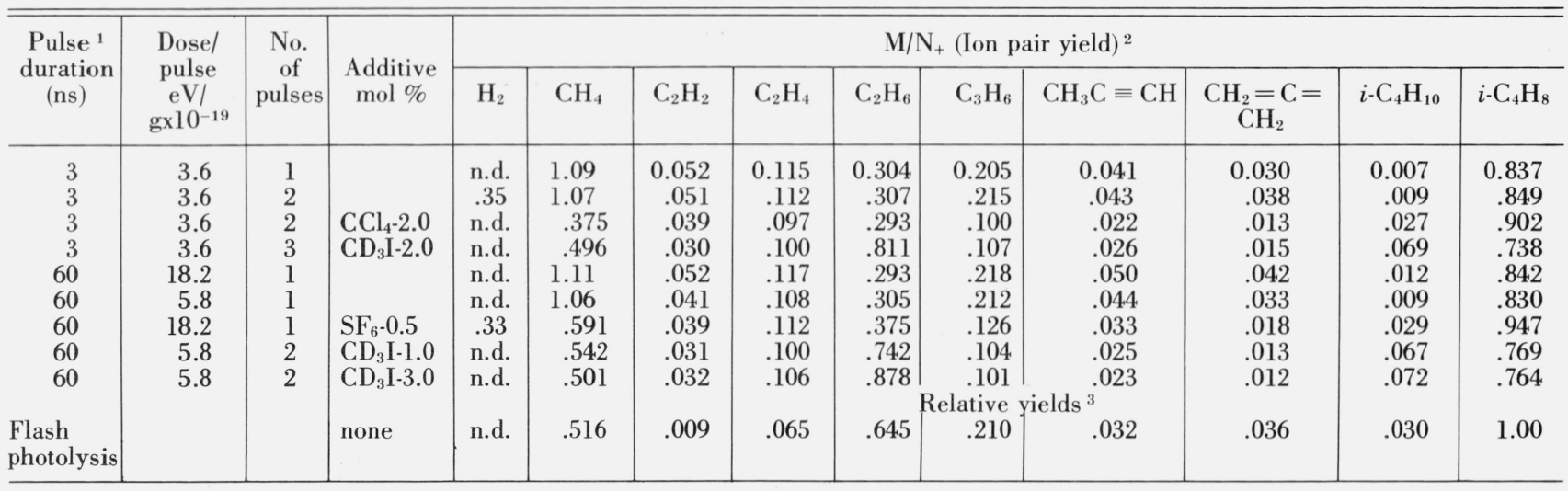

${ }^{1}$ Full width half maximum.

2 Pressure neopentane $=162$ torr.

${ }^{3}$ Pressure neopentane $=5.0$ torr.

n.d. = not determined.

TABLE 2. Pulse radiolysis of neo- $\mathrm{C}_{5} \mathrm{D}_{12}-$ neo- $\mathrm{C}_{5} \mathrm{H}_{12}(1: 1)$ isotopic compositions of ethane and methane

\begin{tabular}{|c|c|c|c|c|c|c|c|}
\hline \multirow{2}{*}{$\begin{array}{l}\text { Dose/pulse } \\
\mathrm{eV} / \mathrm{g} \times 10^{-19}\end{array}$} & \multirow{2}{*}{$\begin{array}{l}\text { Additive } \\
\text { mole \% }\end{array}$} & \multicolumn{5}{|c|}{ Ethane distribution (\%) } & \multirow{2}{*}{$\frac{\mathrm{M} / \mathrm{N}_{+}}{\left(\mathrm{C}_{2} \mathrm{H}_{5}^{+}+\mathrm{C}_{2} \mathrm{D}_{5}^{+}\right)}$} \\
\hline & & $\mathrm{C}_{2} \mathrm{H}_{6}$ & $\mathrm{C}_{2} \mathrm{H}_{5} \mathrm{D}$ & $\mathrm{C}_{2} \mathrm{H}_{3} \mathrm{D}_{3}$ & $\mathrm{C}_{2} \mathrm{D}_{5} \mathrm{H}$ & $\mathrm{C}_{2} \mathrm{D}_{6}$ & \\
\hline \multirow{2}{*}{$\begin{array}{c}\text { Pulse radiolysis: } \\
18.2 \\
18.2 \\
3.6 \\
\text { Low Dose Rate } \\
\text { Radiolysis (ref. 3): }\end{array}$} & $\begin{array}{l}\text { none } \\
\text { SF }_{6}-1.0 \\
\text { NO-3.0 }\end{array}$ & $\begin{array}{l}26.5 \\
26.5 \\
27.5\end{array}$ & $\begin{array}{r}5.5 \\
4.4 \\
18.0\end{array}$ & $\begin{array}{l}37.6 \\
41.3 \\
13.0\end{array}$ & $\begin{array}{r}5.0 \\
4.0 \\
16.5\end{array}$ & $\begin{array}{l}23.7 \\
22.1 \\
25.0\end{array}$ & \multirow[t]{2}{*}{$\begin{array}{r}0.062 \\
.060 \\
.047\end{array}$} \\
\hline & NO-5.0 & 29.5 & 20.5 & & 21.2 & 28.8 & \\
\hline \multirow{4}{*}{$\begin{array}{c}\text { Pulse radiolysis: } \\
18.2 \\
18.2 \\
3.6 \\
\text { Low Dose Rate } \\
\text { Radiolysis (ref. 3): }\end{array}$} & \multirow[b]{3}{*}{$\begin{array}{l}\text { none } \\
\mathrm{SF}_{6}-1.0 \\
\text { NO-3.0 }\end{array}$} & \multicolumn{5}{|c|}{ Methane distribution (\%) } & \multirow{2}{*}{$\begin{array}{c}\mathrm{M} / \mathrm{N}_{+} \\
\text {(Molecular } \\
\text { methane) }\end{array}$} \\
\hline & & $\mathrm{CH}_{4}$ & $\mathrm{CH}_{3} \mathrm{D}$ & $\mathrm{CH}_{2} \mathrm{D}_{2}$ & $\mathrm{CHD}_{3}$ & $\mathrm{CD}_{4}$ & \\
\hline & & $\begin{array}{l}30.8 \\
35.2 \\
42.6\end{array}$ & $\begin{array}{r}16.0 \\
13.0 \\
7.3\end{array}$ & $\begin{array}{l}2.6 \\
2.0\end{array}$ & $\begin{array}{l}27.5 \\
22.5 \\
12.2\end{array}$ & $\begin{array}{l}23.1 \\
27.3 \\
37.9\end{array}$ & $\begin{array}{r}\sim 0.11 \\
.16 \\
.16\end{array}$ \\
\hline & NO-5.0 & 44.3 & 4.3 & & 5.2 & 46.2 & .18 \\
\hline
\end{tabular}

Pressure of neopentane: pulse radiolysis 160 torr, low dose rate radiolysis (ref. 3) 40 torr.

the positive ions. In order to obtain information about this, one must examine all of the free radical and ionmolecule reactions which occur during and immediately after the pulse. Only when end products resulting from these reactions are accounted for, can one proceed to derive concrete information concerning the chemical consequences of the encounters between the unreactive positive ions and the negatively charged species.

Passage of an electron beam through neopentane will lead to the production of electronically excited neutral molecules and of excited parent ions [3]. These species are expected to dissociate within $10^{-12}$ to $10^{-13} \mathrm{~s}[11,12]$, and the following dissociative processes have been invoked to account for the products observed in the low dose rate experiments.

$$
\begin{aligned}
\mathrm{C}_{5} \mathrm{H}_{12}^{*} & \rightarrow i-\mathrm{C}_{4} \mathrm{H}_{8}+\mathrm{CH}_{3}+\mathrm{H} \\
& \rightarrow \mathrm{C}_{3} \mathrm{H}_{6}+\mathrm{CH}_{3}+\mathrm{CH}_{3} \\
& \rightarrow i-\mathrm{C}_{4} \mathrm{H}_{8}+\mathrm{CH}_{4} \\
\mathrm{C}_{5} \mathrm{H}_{12}^{+} & \rightarrow i-\mathrm{C}_{4} \mathrm{H}_{9}^{+}+\mathrm{CH}_{3} \\
& \rightarrow i-\mathrm{C}_{4} \mathrm{H}_{8}^{+}+\mathrm{CH}_{4} \\
& \rightarrow \mathrm{C}_{3} \mathrm{H}_{5}^{+}+\mathrm{CH}_{3}+\mathrm{CH}_{4} \\
& \rightarrow \mathrm{C}_{2} \mathrm{H}_{5}^{+}+\mathrm{CH}_{3}+\mathrm{C}_{2} \mathrm{H}_{4} \\
& \rightarrow \mathrm{C}_{2} \mathrm{H}_{3}^{+}+\mathrm{H}_{2}+\mathrm{CH}_{3}+\mathrm{C}_{2} \mathrm{H}_{4} \\
& \rightarrow \mathrm{C}_{3} \mathrm{H}_{3}^{+}+\mathrm{H}_{2}+\mathrm{CH}_{3}+\mathrm{CH}_{4}
\end{aligned}
$$


TABLE 3. Pulse radiolysis of neo $-\mathrm{C}_{5} \mathrm{D}_{12}-$ neo $-\mathrm{C}_{5} \mathrm{H}_{12}(1: 1)$ isotopic compositions of ethylene and propylene

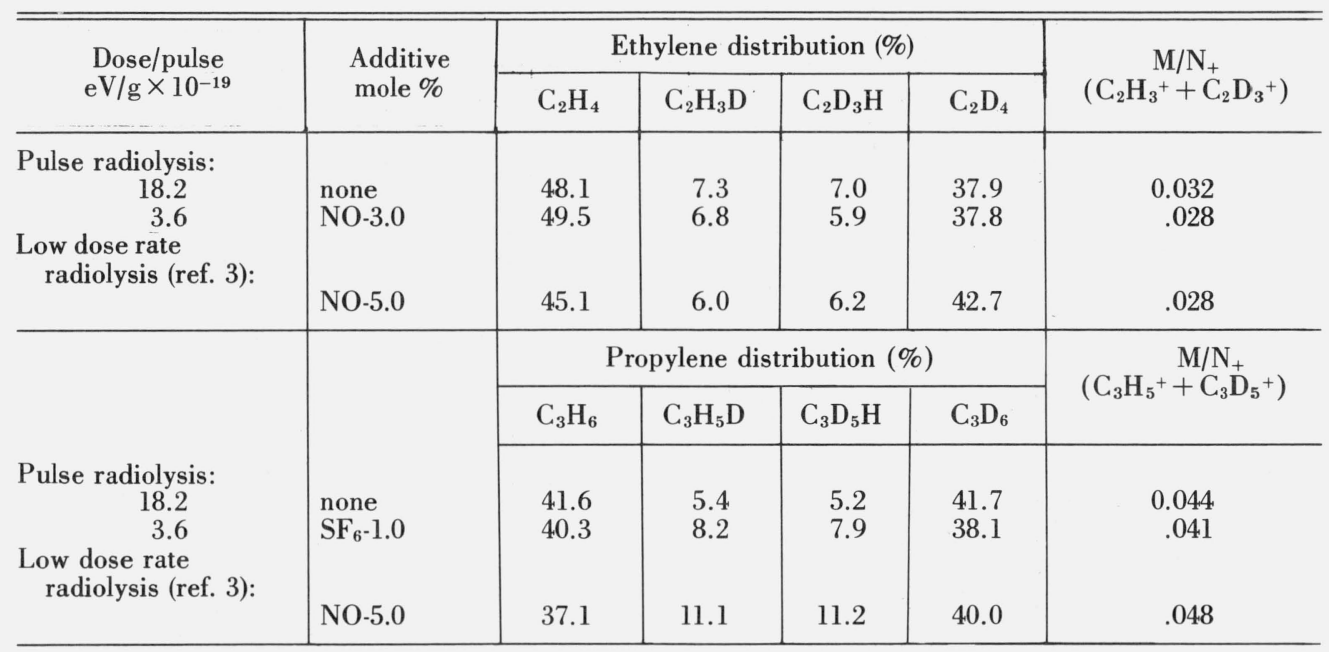

Pressure of neopentane: pulse radiolysis 160 torr, low dose rate radiolysis (ref. 3) 40 torr.

TABLE 4. Pulse radiolysis of neo- $\mathrm{C}_{5} \mathrm{H}_{12}-\mathrm{CD}_{3} \mathrm{I}$ mixtures

\begin{tabular}{|c|c|c|c|c|c|c|c|c|c|c|}
\hline \multirow{2}{*}{$\begin{array}{l}\mathrm{CD}_{3} \mathrm{I} \\
\mathrm{mol} \mathrm{\%}\end{array}$} & \multicolumn{7}{|c|}{$\mathrm{M} / \mathrm{N}_{+}$(Ion Pair Yields) } & \multirow{2}{*}{$\mathrm{CH}_{4_{\text {corr }}} / \mathrm{CD}_{3} \mathrm{H}^{\mathrm{a}}$} & \multirow{2}{*}{$\begin{array}{l}{\left[\mathrm{CH}_{3}\right] /\left[\mathrm{CD}_{3}\right]} \\
\mathrm{CD}_{3} \mathrm{CH}_{3} / 2 \mathrm{C}_{2} \mathrm{D}_{6}\end{array}$} & \multirow{2}{*}{$\mathrm{C}_{2} \mathrm{H}_{6}{ }_{\text {corr }}^{1 / 2} / \mathrm{C}_{2} \mathrm{D}_{6}^{1 / 2}$} \\
\hline & $\mathrm{H}_{2}$ & HD & $\mathrm{CD}_{3} \mathrm{H}$ & $\mathrm{CH}_{4}$ & $\mathrm{C}_{2} \mathrm{D}_{6}$ & $\mathrm{CD}_{3} \mathrm{CH}_{3}$ & $\mathrm{C}_{2} \mathrm{H}_{6}$ & & & \\
\hline $\begin{array}{l}1 \\
3.1 \\
6.1\end{array}$ & $\begin{array}{l}.30 \\
.32\end{array}$ & $\begin{array}{l}.006 \\
.013\end{array}$ & $\begin{array}{l}.184 \\
.176 \\
.184\end{array}$ & $\begin{array}{l}.358 \\
.325 \\
.312\end{array}$ & $\begin{array}{l}.147 \\
.225 \\
.280\end{array}$ & $\begin{array}{l}.330 \\
.413 \\
.472\end{array}$ & $\begin{array}{l}.254 \\
.240 \\
.259\end{array}$ & $\begin{array}{l}1.08 \\
0.94 \\
0.83\end{array}$ & $\begin{array}{r}1.12 \\
0.92 \\
.84\end{array}$ & $\begin{array}{r}1.18 \\
0.92 \\
.86\end{array}$ \\
\hline
\end{tabular}

Dose per pulse: $5.8 \times 10^{19} \mathrm{eV} / \mathrm{g}$.

${ }^{\text {a }} \mathrm{CH}_{4}$ corr : measured yield of $\mathrm{CH}_{4}$ minus contribution due to reactions $3,5,6$, and 9.

${ }^{b} \mathrm{C}_{2} \mathrm{H}_{6}{ }_{\text {corr }}$ : measured yield of $\mathrm{C}_{2} \mathrm{H}_{6}$ minus contribution due to reaction 19 .

Propyl ions are also produced but at a neopentane pressure of 300 torr [3], $\mathrm{M}\left(\mathrm{C}_{3} \mathrm{H}_{7}^{+}\right) / \mathrm{N}_{+}=0.01$.

Process 4 is the major mode of fragmentation of $\mathrm{C}_{5} \mathrm{H}_{12}^{+}$. At a pressure of 150 torr, $\mathrm{M}\left(t-\mathrm{C}_{4} \mathrm{H}_{9}^{+}\right) / \mathrm{N}_{+}$has been estimated [3] to be 0.75 , while $\mathrm{M}\left(i-\mathrm{C}_{4} \mathrm{H}_{8}^{+}\right) / \mathrm{N}_{+}$ has been estimated at 0.03 . Concrete information concerning relative importances of the neutral dissociative processes is not available. Far ultraviolet photolysis experiments indicate however that process 1 is more important than processes 2 or 3 . The total number of neutral electronically excited molecules $\left(\mathrm{C}_{5} \mathrm{H}_{12}^{*}\right)$ per positive ion, $\mathrm{N}_{\mathrm{ex}} / \mathrm{N}_{i}$, in the gas phase radiolysis is not exactly known. On the basis of low dose rate experiments an estimated value of 0.2 has been assigned to $\mathrm{N}_{\text {ex }} / \mathrm{N}_{i}$ (number of neutral excited molecules per ion pair). Later in the discussion an attempt is made to derive more definitive information concerning the role of the neutral dissociative processes.

\subsection{Yields of Fragment lons}

Partially labeled hydrocarbon products such as $\mathrm{C}_{2} \mathrm{D}_{5} \mathrm{H}, \mathrm{C}_{2} \mathrm{D}_{3} \mathrm{H}$, and $\mathrm{C}_{3} \mathrm{D}_{5} \mathrm{H}$ which were also seen in low dose rate experiments carried out in the presence of NO (tables 2 and 3), can be axcribed to the exothermic hydride ion transfer reactions:

$$
\begin{aligned}
& \mathrm{C}_{2} \mathrm{D}_{5}^{+}+\text {neo- } \mathrm{C}_{5} \mathrm{H}_{12} \rightarrow \mathrm{C}_{2} \mathrm{D}_{5} \mathrm{H}+\mathrm{C}_{5} \mathrm{H}_{11}^{+} \\
& \mathrm{C}_{2} \mathrm{D}_{3}^{+}+\text {neo- } \mathrm{C}_{5} \mathrm{H}_{12} \rightarrow \mathrm{C}_{2} \mathrm{D}_{3} \mathrm{H}+\mathrm{C}_{5} \mathrm{H}_{11}^{+} \\
& \mathrm{C}_{3} \mathrm{D}_{5}^{+}+\text {neo- } \mathrm{C}_{5} \mathrm{H}_{12} \rightarrow \mathrm{C}_{3} \mathrm{D}_{5} \mathrm{H}+\mathrm{C}_{5} \mathrm{H}_{11}^{+}
\end{aligned}
$$

Because the rate constants of these reactions are approximately $10^{-9} \mathrm{~cm}^{3} / \mathrm{molec} \cdot \mathrm{s}[13]$, more than 99 percent of the $\mathrm{C}_{2} \mathrm{D}_{5}^{+}, \mathrm{C}_{2} \mathrm{D}_{3}^{+}$and $\mathrm{C}_{3} \mathrm{D}_{5}^{+}$will react with neopentane even at the highest dose rates used in this study.

If, as in the earlier low dose rate studies [3], one accepts that in fast ion-molecule reactions, isotope effects can be ignored, maximum ion pair yields of the three reactant ions can be obtained by multiplying the sums of ion pair yields of $\mathrm{C}_{2} \mathrm{D}_{5} \mathrm{H}+\mathrm{C}_{2} \mathrm{DH}_{5}, \mathrm{C}_{2} \mathrm{D}_{3} \mathrm{H}+$ $\mathrm{C}_{2} \mathrm{DH}_{3}$, and $\mathrm{C}_{3} \mathrm{D}_{5} \mathrm{H}+\mathrm{C}_{3} \mathrm{DH}_{5}$ by a factor of two. The values thus obtained are given in the last column of tables 2 and 3 . They compare rather well with those derived from low dose rate experiments carried out at a lower pressure of neopentane in the presence of $\mathrm{NO}$ as a free radical interceptor. At low dose rates, low concentrations of $\mathrm{NO}$ or $\mathrm{O}_{2}$ will effectively remove free radicals from the system, and thus prevent contributions of radical-radical interactions to the partially labeled hydrocarbon products. Nitric oxide or oxygen 
are obviously less efficient as free radical scavengers under our pulse radiolysis conditions. At high dose rates radical-radical interactions will compete with radical-scavenger molecule ractions. Nevertheless, using a $3 \mathrm{~ns}$ pulse and a dose of $1.8 \mathrm{eV} / \mathrm{g}$ per pulse, the methyl radicals which, according to processes 1 through 8, are the most abundant alkyl radicals produced during the pulse, can be removed to a significant extent upon addition of $5 \mathrm{~mol}$ percent $\mathrm{NO}$ to neopentane. This is demonstrated by the pronounced drop of $\mathrm{M}\left(\mathrm{CH}_{4}\right) / \mathrm{N}_{+}$and $\mathrm{M}\left(\mathrm{C}_{2} \mathrm{H}_{6}\right) / \mathrm{N}_{+}$as a function of the pressure of $\mathrm{NO}$ as seen in figure 1.

Furthermore the $\mathrm{CH}_{3} \mathrm{CD}_{3}$ which can be unambiguously ascribed to the radical combination reaction

$$
\mathrm{CH}_{3}+\mathrm{CD}_{3} \rightarrow \mathrm{CH}_{3} \mathrm{CD}_{3}
$$

diminishes sharply with respect to the other partially deuterium labeled ethanes when NO is added (table 2). The ion pair yield of 0.047 for the ethyl ions derived from this experiment can be considered as more reliable than the 0.060 calculated from the isotopic ethane distributions observed in the unscavenged experiments (table 2). The value obtained for M(ethyl ion)/ $\mathrm{N}_{+}$is bracketed by the low dose rate values of 0.068 and 0.035 obtained at neopentane pressures of 30 and 300 torr respectively [3]. The drop of $\mathrm{M}\left(\mathrm{C}_{2} \mathrm{H}_{5}^{+}\right)$/ $\mathrm{N}_{+}$with pressure has been ascribed [3] to collisional quenching of process 7 .

\subsection{Yields of Molecular $\mathrm{CH}_{4}$ and $\mathrm{CH}_{3}$}

The total yield of molecular methane formed by the fragmentation processes 3,5 , and 6 can be estimated from the isotopic analysis given in table 2 assuming one

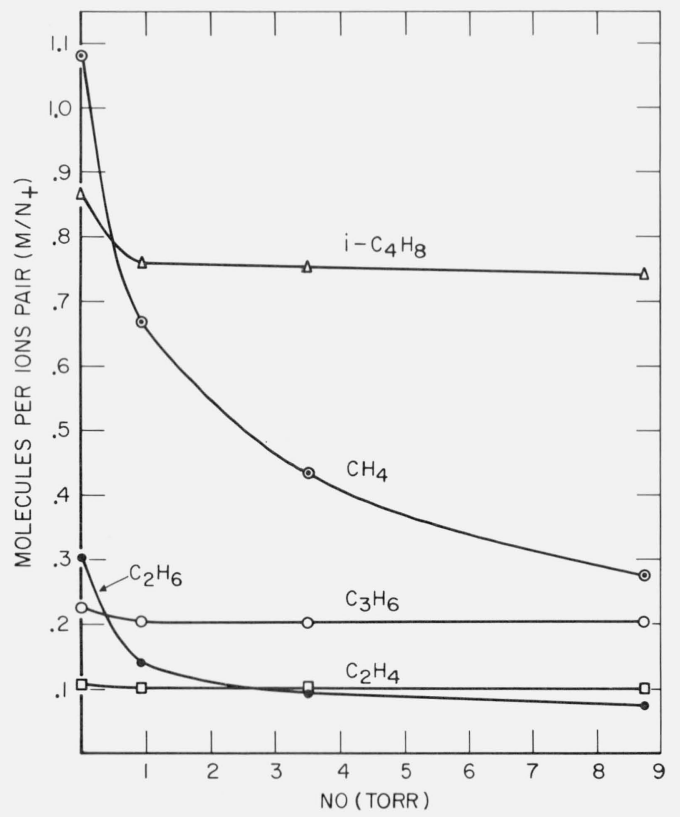

FIGURE 1. The effect of NO on the major hydrocarbon products formed in the pulse radiolysis of neopentane $\left(3 \mathrm{~ns}, 3.6 \mathrm{eV} / \mathrm{g} \times 10^{19}\right)$.

Pressure of neopentane: 162 torr. molecule of $\mathrm{CD}_{4}$ or $\mathrm{CH}_{4}$ is being produced for each molecule of $\mathrm{CH}_{3} \mathrm{D}$ or $\mathrm{CD}_{3} \mathrm{H}$. In the pulse radiolysis of pure neo- $\mathrm{C}_{5} \mathrm{D}_{12}$-neo- $\mathrm{C}_{5} \mathrm{H}_{12}$ mixtures there is considerable isotopic mixing (table 2) due to the combination reactions

$$
\begin{aligned}
& \mathrm{CH}_{3}+\mathrm{D} \rightarrow \mathrm{CH}_{3} \mathrm{D} \\
& \mathrm{CD}_{3}+\mathrm{H} \rightarrow \mathrm{CD}_{3} \mathrm{H} .
\end{aligned}
$$

Addition of $5 \mathrm{~mol}$ percent NO drastically reduces the total methane yield (fig. 1), and more specifically, the relatively abundances of $\mathrm{CD}_{3} \mathrm{H}$ and $\mathrm{CH}_{3} \mathrm{D}$ in the methane fraction. From such an experiment, a reliable value of 0.16 is obtained for the ion pair yield of molecular methane. Because of the large relative yields of $\mathrm{CH}_{3} \mathrm{D}$ and $\mathrm{CD}_{3} \mathrm{H}$ the value for molecular methane derived from the isotopic distribution observed in pure neo- $\mathrm{C}_{5} \mathrm{H}_{12}$-neo- $\mathrm{C}_{5} \mathrm{D}_{12}$ mixtures is obviously less reliable. In the $\mathrm{C}_{5} \mathrm{D}_{12}-\mathrm{C}_{5} \mathrm{H}_{12}-\mathrm{SF}_{6}$ experiment, where the total methane yield (table 1 ) and the relative contributions of $\mathrm{CD}_{3} \mathrm{H}$ and $\mathrm{CH}_{3} \mathrm{D}$, are lower, good agreement is obtained. Taking $\mathbf{M}(i$ $\left.\mathrm{C}_{4} \mathrm{H}_{8}^{+}\right) / \mathrm{N}_{+}=\sim 0.03[3]$ (process 5) and $\mathrm{M}\left(\mathrm{C}_{3} \mathrm{H}_{5}^{+}\right) / \mathrm{N}_{+}=$ 0.044 (process 6) more than half of the yield of molecular methane remains unaccounted for. If one tentatively accepts that as indicated by the $70 \mathrm{eV}$ mass spectral pattern $\mathrm{C}_{3} \mathrm{H}_{3}^{+}$is slightly less abundant than $\mathrm{C}_{2} \mathrm{H}_{3}^{+}$, "one obtains a value approximately 0.10 for the molecular methane produced by fragmentation of $\mathrm{C}_{5} \mathrm{H}_{12}^{+}$.

$\mathrm{M}\left(\mathrm{CH}_{3}\right) / \mathrm{N}_{+}$can be estimated by summation of all the products which can be ascribed to combination of $\mathrm{CH}_{3}$ with other radicals in the system

$$
\mathrm{CH}_{3}+\mathrm{R} \rightarrow \mathrm{CH}_{3} \mathrm{R}
$$

where $R=\mathrm{H}, \mathrm{CH}_{3},\left(\mathrm{CH}_{3}\right)_{3} \mathrm{CCH}_{2}$. In view of the absence of $\mathrm{C}_{3} \mathrm{H}_{3} \mathrm{D}_{3}$ in the propylene fraction a reaction such as

$$
\mathrm{C}_{2} \mathrm{H}_{3}\left(\mathrm{C}_{2} \mathrm{D}_{3}\right)+\mathrm{CD}_{3}\left(\mathrm{CH}_{3}\right) \rightarrow \mathrm{C}_{3} \mathrm{H}_{3} \mathrm{D}_{3}
$$

does not occur and vinyl radicals are therefore not produced in the pulse radiolysis of pure neopentane. Similarly, the negligible contribution of $\mathrm{C}_{4} \mathrm{D}_{5} \mathrm{H}_{3}$ to the isobutene fraction and the absence of 1-butene as a product indicates that allyl radicals play a very minor role. Finally, the minor yield of propane (see Results) points to a low abundance of ethyl radicals which if formed would mainly combine with $\mathrm{CH}_{3}$.

After taking into account the contributions of molecular methane and $\mathrm{C}_{2} \mathrm{H}_{5}^{+}$to the methane and ethane fractions respectively, a value of $1.48 \pm 0.02$ is obtained for $\mathrm{M}\left(\mathrm{CH}_{3}\right) / \mathrm{N}_{+}$in the pulse radiolysis of pure neopentane. A slightly higher value $(1.5 \pm 0.02)$ is obtained if one assumes that $\mathrm{C}_{3} \mathrm{H}_{8}$ and $i-\mathrm{C}_{4} \mathrm{H}_{10}$ are produced entirely by combination of $\mathrm{CH}_{3}$ radicals with $\mathrm{C}_{2} \mathrm{H}_{5}$ and $\mathrm{C}_{3} \mathrm{H}_{7}$ respectively. A change in pulse duration, dose or dose rate has, within experimental error, no effect on the estimated yield of $\mathrm{CH}_{3}$ radicals. The value for $\mathrm{M}\left(\mathrm{CH}_{3}\right) / \mathrm{N}_{+}$obtained here is in close agreement with the value of 1.45 reported for $\mathrm{M}\left(\mathrm{CD}_{3} \mathrm{H}\right) / \mathrm{N}_{+}$ produced in the low dose rate radiolysis of neo- $\mathrm{C}_{5} \mathrm{D}_{12}$ carried out in the presence of $\mathrm{H}_{2} \mathrm{~S}$ as a free radical 
interceptor [3]. Accepting [3] a value of 0.03 for $\mathrm{M}\left(\mathrm{i}-\mathrm{C}_{4} \mathrm{H}_{8}^{+}\right) / \mathrm{N}_{+}$the total ion pair of $\mathrm{CH}_{3}$ resulting from the decomposition of the parent ion (reactions 4, 6 through 9) cannot be higher than 0.97. Since the total yield of methyl radicals derived above is $\sim 1.5$, it follows that $\mathrm{CH}_{3}$ radicals are produced from other sources, such as the decomposition of electronically excited neopentane (processes 1 and 2) and of internally excited radicals produced by neutralization.

In order to verify the modes of formation of the methane and ethane products, the pulse radiolysis of neo- $\mathrm{C}_{5} \mathrm{H}_{12}$ containing from 1 to $6.1 \mathrm{~mol}$ percent $\mathrm{CD}_{3} \mathrm{I}$ (table 4) was investigated. Addition of $\mathrm{CD}_{3} \mathrm{I}$ has the effect of introducing $\mathrm{CD}_{3}$ radicals to the system, mainly by the dissociative electron capture step

$$
\mathrm{CD}_{3} \mathrm{I}+e \rightarrow \mathrm{CD}_{3}+\mathrm{I}^{-} .
$$

Provided the concentration of $\mathrm{CD}_{3} \mathrm{I}$ is sufficiently low, there should be no interference with hydride ion transfer reaction,

$$
\mathrm{C}_{2} \mathrm{H}_{5}^{+}+\text {neo- } \mathrm{C}_{5} \mathrm{H}_{12} \rightarrow \mathrm{C}_{2} \mathrm{H}_{6}+\mathrm{C}_{5} \mathrm{H}_{11}^{+}
$$

and the free radicals should react in the same way as in pure neopentane. As expected on the basis of the free radical combination reaction discussed above, the methane is seen to consist exclusively of $\mathrm{CD}_{3} \mathrm{H}$ and $\mathrm{CH}_{4}$, while the ethane fraction contains, $\mathrm{C}_{2} \mathrm{D}_{6}$, $\mathrm{CD}_{3} \mathrm{CH}_{3}, \mathrm{C}_{2} \mathrm{H}_{6}$ and no other partially deuterated ethanes. If one now subtracts from $\mathrm{M}\left(\mathrm{CH}_{4}\right) / \mathrm{N}_{+}$the contribution of molecular methane, and from $\mathrm{C}_{2} \mathrm{H}_{6}$ the contribution due to the reaction 19 , one obtains consistent values for $\mathrm{CH}_{3} / \mathrm{CD}_{3}$ as calculated from the product ratios given in the last three columns of table 4. It follows that the mechanism proposed for the formation of methane and ethane is well substantiated.

\subsection{Formation of Hydrogen}

Apparently, the majority of the $\mathrm{H}$-atoms react with $\mathrm{CH}_{3}$ to produce methane. On the basis of the results presented in tables 1 and 2 , a value of 0.9 can be ascribed to the ion pair yield of $\mathrm{H}$-atoms reacting in this manner. In addition, one has to consider the $\mathrm{H}_{2}$ which is observed in all experiments. The mechanism by which this product is formed is not immediately obvious. Although the relatively low yield of $\mathrm{HD}$ observed in the pulse radiolysis of $\mathrm{C}_{5} \mathrm{H}_{12}-\mathrm{C}_{5} \mathrm{D}_{12}$ mixtures, (see Results) indicates that some of the hydrogen is eliminated unimolecularly from excited intermediates, a considerable fraction must be produced via bimolecular reactions. At least some of the HD may be formed in the hydrogen abstraction reaction

$$
\mathrm{H}^{*}+\mathrm{C}_{5} \mathrm{H}_{12} \rightarrow \mathrm{H}_{2}+\mathrm{C}_{5} \mathrm{H}_{11}
$$

where $\mathrm{H}^{*}$ designates a translationally excited atom. The presence of 2,2-dimethylbutane $\left(\mathrm{M} / \mathrm{N}_{+}=0.055 \pm\right.$ 0.05 ) can be explained by the combination of the resulting neopentyl radicals with methyl radicals.
(The yield of this product is reduced in the presence of 5 percent $\mathrm{NO}$, confirming the participation of a radical mechanism in its formation.)

Combination of $\mathrm{H}$-atoms is excluded as a major source of $\mathrm{HD}$, in view of the fact that addition of electron scavengers such as $\mathrm{SF}_{6}$ and $\mathrm{CD}_{3} \mathrm{I}$ reduces $\mathrm{M}(\mathrm{H}) / \mathrm{N}_{+}$, (as indicated by the sharp drop of $\mathrm{M}\left(\mathrm{CH}_{4}\right) / \mathrm{N}_{+}$ in these experiments) (table 1), but has no noticeable effect on either the yield of hydrogen or its isotopic composition.

\subsection{Neutralization}

The ions which under the present pulse radiolysis conditions will undergo homogeneous neutralization are: $\mathrm{C}_{4} \mathrm{H}_{9}^{+}, \mathrm{C}_{4} \mathrm{H}_{8}^{+}, \mathrm{C}_{3} \mathrm{H}_{3}^{+}$produced in the unimolecular fragmentation steps, and $\mathrm{C}_{5} \mathrm{H}_{11}^{+}$produced via the hydride ion transfer reactions involving $\mathrm{C}_{2} \mathrm{H}_{3}^{+}, \mathrm{C}_{2} \mathrm{H}_{5}^{+}$, and $\mathrm{C}_{3} \mathrm{H}_{5}^{+}$. The total ion pair yield of $\mathrm{C}_{5} \mathrm{H}_{11}^{+}$can be estimated at $0.12 \pm 0.01$ and that of $t-\mathrm{C}_{4} \mathrm{H}_{9}^{+}$at 0.80 . The remaining 0.08 being accounted for by $i-\mathrm{C}_{4} \mathrm{H}_{8}^{+}$ $(\sim 0.03), \mathrm{C}_{3} \mathrm{H}_{7}^{+}(\sim 0.01)$, and $\mathrm{C}_{3} \mathrm{H}_{3}^{+}(\sim 0.03)$. It is clear from the quantitative results presented in table 1 that the mechanism of neutralization of the $t-\mathrm{C}_{4} \mathrm{H}_{9}^{+}$ ion can be represented in the same way as recently proposed for the liquid phase radiolysis of neopentane [14]:

$$
\begin{gathered}
t-\mathrm{C}_{4} \mathrm{H}_{9}^{+}+e \rightarrow t-\mathrm{C}_{4} \mathrm{H}_{9}^{*} \quad \Delta H=-5.17 \mathrm{eV} \\
t-\mathrm{C}_{4} \mathrm{H}_{9}^{*} \rightarrow i-\mathrm{C}_{4} \mathrm{H}_{8}+\mathrm{H} \\
\rightarrow \mathrm{C}_{3} \mathrm{H}_{6}+\mathrm{CH}_{3} .
\end{gathered}
$$

The $t-\mathrm{C}_{4} \mathrm{H}_{9}^{*}$ radical produced initially will possess $5.17 \mathrm{eV}$ in internal energy [15] and will therefore dissociate essentially instantaneously [16]. Step 21, which on the basis of pyrolysis studies [17] requires an activation energy of $1.9 \mathrm{eV}$, is the expected mode of decomposition of internally excited $t-\mathrm{C}_{4} \mathrm{H}_{9}$ radicals. Decomposition step 22 which, in pyrolysis carried out at temperatures up to $857 \mathrm{~K}$, plays a very minor role, is however of importance in the low intensity photolysis of neopentane at 147 and $123.6 \mathrm{~nm}$ [3] as well as in the flash photolysis (table 1). The internal energy content of the intermediate $t-\mathrm{C}_{4} \mathrm{H}_{9}^{*}$ radical, which in the photolysis is produced by cleavage of a $\mathrm{C}-\mathrm{C}$ bond in neopentane, is comparable to that produced in the neutralization step. It is matter of conjecture if the $t-\mathrm{C}_{4} \mathrm{H}_{9}^{*}$ isomerizes first to the $i-\mathrm{C}_{4} \mathrm{H}_{9}^{*}$ structure or if a $\mathrm{CH}_{3} \mathrm{CCH}_{3}$ diradical is produced by a simple $\mathrm{C}-\mathrm{C}$ cleavage of the $t-\mathrm{C}_{4} \mathrm{H}_{9}^{*}$ intermediate followed by isomerization to propylene. It is of interest, however, that isobutyl radicals have been reported in the liquid phase radiolysis [18] where some of the $\mathrm{C}_{4} \mathrm{H}_{9}^{*}$ may be collisionally stabilized. The branching ratio of steps 21 and 22 can be estimated by the decrement of $\mathrm{M}\left(\mathrm{C}_{3} \mathrm{H}_{6}\right) / \mathrm{N}_{+}$noted when an electron scavenger such as $\mathrm{SF}_{6}, \mathrm{CCl}_{4}$, or $\mathrm{CD}_{3} \mathrm{I}$ is added to neopentane (see table 1). In view of the high electron capture cross section of these molecules [19], a few mole percent should be sufficient to capture the 
majority of the electrons under the pulse radiolysis conditions. This is indicated by the observation (table 4) that in the case of the least efficient electron scavenger, $\mathrm{CD}_{3} \mathrm{I}, \mathrm{M}\left(\mathrm{CD}_{3}\right) / \mathrm{N}_{+}$which is mainly produced by the dissociative electron attachment process 18 reaches values of 0.81 and 1.05 upon addition of 1 and 3 mol percent $\mathrm{CD}_{3} \mathrm{I}$ respectively. Neutralization of a positive ion by collision with a negative ion rather than an electron will impart less energy to the neutral entity formed in the process. The electron affinity of the scavenger molecule will result in the formation of a negative ion with a greater heat of formation than the electron, so the neutralization reaction is less exothermic, and the energy content of the neutralized species will be lowered. As is indicated by the reduction of $\mathrm{M}(\mathrm{H}) / \mathrm{N}_{+}$in the presence of an electron scavenger, the energy may be further reduced because of the occurrence of chemical reactions such as

$$
\begin{gathered}
\mathrm{C}_{4} \mathrm{H}_{9}^{+}+\mathrm{I}^{-} \rightarrow \mathrm{HI}+i-\mathrm{C}_{4} \mathrm{H}_{8} \\
\mathrm{C}_{4} \mathrm{H}_{9}^{+}+\mathrm{SF}_{6}^{-} \rightarrow \mathrm{HF}+\mathrm{SF}_{5}+i-\mathrm{C}_{4} \mathrm{H}_{8} .
\end{gathered}
$$

Reduction of hydrogen atom production by electron scavengers have also been reported in numerous low dose rate radiolysis studies [20] of alkanes and cycloalkanes.

Addition of $\mathrm{CD}_{3} \mathrm{I}$ reduces $\mathrm{M}\left(\mathrm{C}_{3} \mathrm{H}_{6}\right) / \mathrm{N}_{+}$from 0.21 \pm 0.05 to 0.10 , independent of the concentration of $\mathrm{CD}_{3} \mathrm{I}$. $\mathrm{CCl}_{4}$ has the same effect as $\mathrm{CD}_{3} \mathrm{I}$, while $\mathrm{SF}_{6}$ seems to reduce the yield somewhat less. Accepting, on the basis of the reduction in the yield of $\mathrm{C}_{3} \mathrm{H}_{6}$ in the presence of $\mathrm{CD}_{3} \mathrm{I}$, a value of 0.11 for the ion pair yield of reaction 22 , one can assume that the remaining $t-\mathrm{C}_{4} \mathrm{H}_{9}^{+}$ions $\left(\mathrm{M} / \mathrm{N}_{+}=0.69\right)$ lead to the production of $i-\mathrm{C}_{4} \mathrm{H}_{8}$ (reaction 21).

The $i-\mathrm{C}_{4} \mathrm{H}_{8}^{*}$ produced in the neutralization of the $i-\mathrm{C}_{4} \mathrm{H}_{8}^{+}$ion

$$
i-\mathrm{C}_{4} \mathrm{H}_{8}^{+}+e \rightarrow i-\mathrm{C}_{4} \mathrm{H}_{8}^{*}
$$

will possess $9.23 \mathrm{eV}$ in energy above the ground state of the $i-\mathrm{C}_{4} \mathrm{H}_{8}$ molecule. It may be assumed that this molecule will dissociate in a manner similar to that observed for $i-\mathrm{C}_{4} \mathrm{H}_{8}^{*}$ molecules excited by absorption of $10 \mathrm{eV}$ photons, namely:

$$
\begin{aligned}
i-\mathrm{C}_{4} \mathrm{H}_{8}^{*} & \rightarrow \mathrm{CH}_{2}=\mathrm{C}=\mathrm{CH}_{2}+\mathrm{H}+\mathrm{CH}_{3} \\
& \rightarrow \mathrm{CH}_{3} \mathrm{C} \equiv \mathrm{CH}+\mathrm{H}+\mathrm{CH}_{3} .
\end{aligned}
$$

Both decompositions occur via a $\mathrm{C}_{4} \mathrm{H}_{7}^{*}$ and/or $\mathrm{C}_{3} \mathrm{H}_{5}^{*}$ intermediate. Methylacetylene and allene are produced in the pulse radiolysis of neopentane (table 1 ), and it can be seen that addition of an electron scavenger reduced $\mathrm{M}\left(\mathrm{C}_{3} \mathrm{H}_{4}\right) / \mathrm{N}_{+}$from $0.075 \pm 0.005$ to $0.040 \pm 0.005$. The decrement corresponds to the ion pair yield of $i$ - $\mathrm{C}_{4} \mathrm{H}_{8}^{+}$. The residual $\mathrm{C}_{3} \mathrm{H}_{4}$ could be produced by decomposition of highly excited neutral fragments produced in the decomposition of electronically excited neopentane. Both allene and methyl-acetylene are minor products in the flash photolysis of neopentane (table 1).

The mechanism of neutralization of the $\mathrm{C}_{5} \mathrm{H}_{11}^{+}$ion is rather straightforward. 2-Methyl-1-butene and 2methyl-2-butene are products in the pulse radiolysis of neopentane (see Results). The fact that their yields are not reduced by addition of $\mathrm{NO}$ shows that they are not formed by a radical combination reaction. Also none of these products was observed in the flash photolysis or low intensity photolysis of neopentane. A logical interpretation involves the neutralization of $\mathrm{C}_{5} \mathrm{H}_{11}^{+}$ions with the structure $\left(\mathrm{CH}_{3}\right)_{2} \mathrm{CCH}_{2} \mathrm{CH}_{3}^{+}$

$$
\begin{aligned}
\left(\mathrm{CH}_{3}\right)_{2} \mathrm{CCH}_{2} \mathrm{CH}_{3}^{+}+e & \rightarrow\left(\mathrm{CH}_{3}\right)_{2} \mathrm{C}=\mathrm{CHCH}_{3}+\mathrm{H} \\
& \rightarrow \mathrm{CH}_{3} \mathrm{CH}_{2} \mathrm{C}\left(\mathrm{CH}_{3}\right)=\mathrm{CH}_{2}+\mathrm{H}
\end{aligned}
$$

process 29 occurring with a probability which is a factor of 2.5 times higher than 28. In view of the fact that in the pulse radiolysis of pure neopentane $\mathrm{M}\left(\mathrm{C}_{5} \mathrm{H}_{10}\right) / \mathrm{N}_{+}=0.09$ it can be assumed that essentially all $\mathrm{C}_{5} \mathrm{H}_{11}^{+}$ions produced in the hydride ion transfer reactions acquire the stable $t-\mathrm{C}_{5} \mathrm{H}_{11}^{+}$structure prior to neutralization. Addition of $\mathrm{SF}_{6}$ raises $\mathrm{M}\left(\mathrm{C}_{5} \mathrm{H}_{10}\right) / \mathrm{N}_{+}$ to $0.12 \pm 0.01$ in good agreement with the ion pair yield of the $\mathrm{C}_{5} \mathrm{H}_{11}^{+}$ions $(0.12)$. It can be surmised that in the absence of $\mathrm{SF}_{6}$ a fraction $\left(\mathrm{M} / \mathrm{N}_{+} \sim 0.03\right)$ of the $\mathrm{C}_{5} \mathrm{H}_{11}^{+}$are neutralized in the following manner:

$$
\left(\mathrm{CH}_{3}\right)_{2} \mathrm{CCH}_{2} \mathrm{CH}_{3}^{+}+e \rightarrow\left(\mathrm{CH}_{3}\right)_{2} \mathrm{CCH}_{2}+\mathrm{CH}_{3} \text {. }
$$

The mechanism of neutralization involving $\mathrm{SF}_{\overline{6}}$ is probably similar to reaction 24 .

Neutralization of the remaining minor ions, $\mathrm{C}_{3} \mathrm{H}_{3}^{+}$ and sec- $\mathrm{C}_{3} \mathrm{H}_{7}^{+}$can not be elucidated. They will probably contribute to formation of highly unsaturated products. The value of $\mathrm{M}\left(\mathrm{C}_{2} \mathrm{H}_{2}\right) / \mathrm{N}_{+}$, for instance, is reduced from 0.051 to $\sim 0.035$ upon addition of electron scavengers.

\subsection{Estimation of the Yield of Electronically Excited Neopentane Molecules}

Table 5 represents a summary of the ion pair yields of free radicals and molecular products, which have been accounted for by the unimolecular dissociation of the parent ion and the major neutralization reactions

TABLE 5. Methyl radicals and hydrocarbon molecules produced in unimolecular dissociation and neutralization reactions

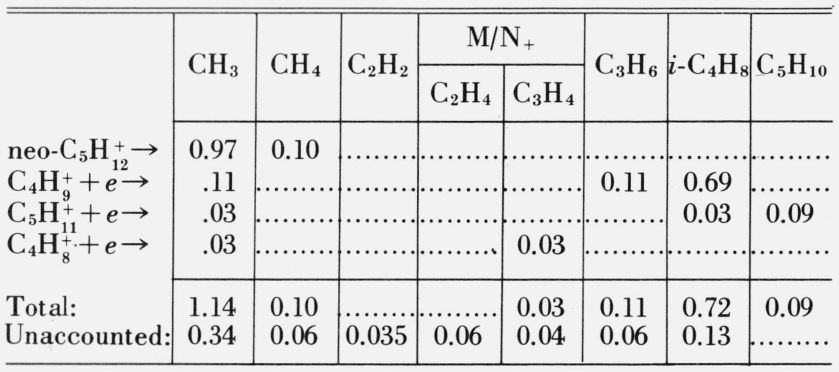


proposed in the previous section. The last row of the table shows the yields of the fragments which are not yet accounted for. An ion pair yield of 0.06 must be ascribed to molecular ethylene which does not enter into any of the reactions listed so far. Even though not all of the ionic processes have been exhaustively covered, the yields given in the last row provide a reasonable balance between the $\mathrm{C}_{1}$ products on one hand and the $\mathrm{C}_{2}, \mathrm{C}_{3}$, and $\mathrm{C}_{4}$ products on the other hand, if one takes into account that two $C_{1}$ fragments will be formed for each $\mathrm{C}_{3}$ fragment. If one tentatively ascribes the unaccounted for products to decomposition of electronically excited neopentane molecules produced by electron impact a value of 0.28 is obtained for $\mathrm{N}_{\text {ex }} / \mathrm{N}_{i}$. This estimated value may admittedly require some revision wherever the minor unexplained reaction steps can be accounted for. It falls however in the same range as the values derived from conventional low dose rate radiolysis experiments on neopentane [3] as well as other alkanes [21].

The authors thank J. H. Sparrow and R. C. Placious for their assistance in using the Febetron 705 and 706.

\section{References}

[1a] Cahill, R. W., Seeler, A. K., and Glass, R. A., J. Phys. Chem. 71, 4564 (1967).

[1b] Hummel, R. W. and Hearne, J. A., J. Phys. Chem. 75, 1164 (1971).

[2] Herzberg, G., Molecular Spectra and Molecular Structure (D. Van Nostrand, Princeton, New Jersey, 1967).

[3a] Lias, S. G. and Ausloos, P., J. Chem. Phys. 43, 2748 (1965).

[3b] Miyazaki, T. and Shida, S., Bull. Chem. Soc. Japan 39, 2344 (1966). [3c] Ausloos, P. and Lias, S. G., J. Am. Chem. Soc. 92, 5037 (1970).

[4] Willis, C., Miller, O: A., Rothwell, A. E., and Boyd, A. W., Advan. in Chem. Ser. 81, 539 (1968).

[5] Field Emission Corporation Technical Bulletin B-21-A.

[6] Kurylo, M. J., Peterson, N. C., and Braun, W., J. Chem. Phys. 53, 2776 (1970).

[7] Willis, C., Boyd, A. W., and Miller, O. A., Radiat. Res. 46, 428 (1971).

[8] Berger, M. J. and Seltzer, S. M., NASA Report SP-3012 (1964).

[9] Woodward, T. W. and Back, R. A., Can. J. Chem. 41, 1463 (1963).

[10] LeBlanc, R. M. and Herman, J. A., J. Chim. Phys. 21, 1055 (1966).

[11] Beckey, H. D., Z. Naturforsch 160,505 (1961).

[12] Ausloos, P., Mol. Photochem. 4, 39 (1972).

[13] Field, F. H. and Lampe, F. W., J. Am. Chem. Soc. 80, 5587 (1958).

[14] Collin, G. J. and Ausloos, P., J. Am. Chem. Soc. 93, 1336 (1971).

[15] Based on the $\Delta H_{f}\left(t-\mathrm{C}_{4} \mathrm{H}_{9}^{+}\right)$value of $7.25 \mathrm{eV}$ reported by Lossing, F. P. and Semelick, G. P., Can. J. Chem. 48, 955 (1970).

[16] Rabinovitch, B. S. and Setser, D. W., Advan. in Photochem. Ser. 3, 1 (1964).

[17] Benson, S. W. and O'Neal, H. E., Kinetic Data on Gas Phase Unimolecular Reactions, Nat. Stand. Ref. Data Ser., Nat. Bur. Stand. (U.S.), 21, 645 pages (Feb. 1970).

[18] Holroyd, R. A. and Klein, G. W., J. Am. Chem. Soc. 87, 4983 (1965).

[19] Blaunstein, R. P. and Christophorou, L. G., J. Chem. Phys. 49, 1526 (1968).

[20] See for instance:

[20a] Bansal, K. M. and Freeman, G. R., J. Am. Chem. Soc. 90, 7183 (1968).

[20b] Johnson, G. R. A. and Redpath, J. L., Trans. Faraday Soc. 66, 861, (1970).

[20c] Sagert, N. H., Reid, J. A., and Robinson, R. W., Can J. Chem. 47, 2655 (1969).

[21] Ausloos, P. and Lias, S. G., Gas Phase Radiolysis of Hydrocarbons in Actions Chimiques et Biologiques des Radiations, Vol. 11, Chapter 1, pp. 1-83, Masson et Cie Editeurs, Paris, France (1967).

(Paper 76A4-724) 